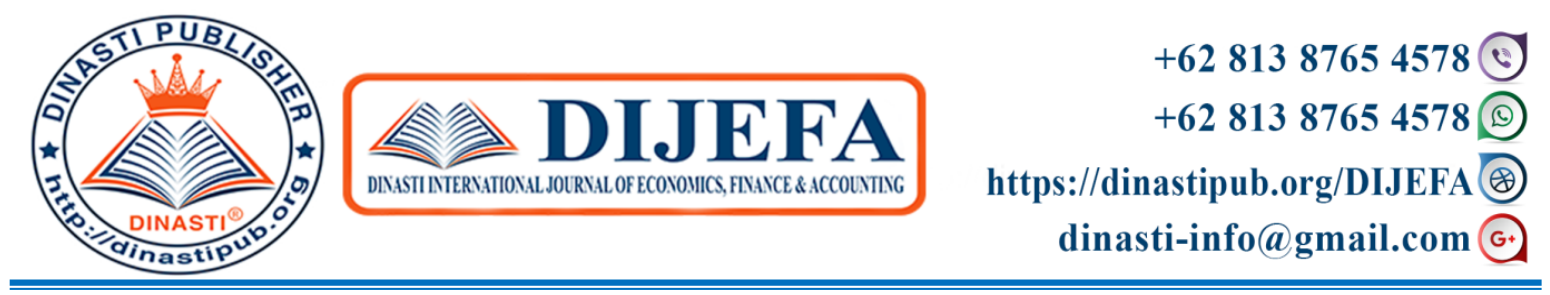

\title{
APPLICATION OF GOOD CORPORATE GOVERNANCE IN PT. UNILEVER INDONESIA
}

\section{Vebina Desi Eka Wati}

Program Pascasarjana, Universitas Mercu Buana, Jakarta, Indonesia

\begin{tabular}{|c|l|}
\hline $\begin{array}{c}\text { ARTICLE INFORMATION } \\
\text { Received: } 20^{\text {th }} \text { May } 2020 \\
\text { Revised: } 20^{\text {th }} \text { June } 2020 \\
\text { Issued: } 6^{\text {th }} \text { August } 2020\end{array}$ & $\begin{array}{l}\text { Abstract: Good Corporate Governance is corporate } \\
\text { governance that explains the relationships between } \\
\text { various participants in the company that determine the } \\
\text { direction of the company's performance. Good } \\
\text { corporate governance is corporate governance that } \\
\text { explains the relationship of the parties participating in } \\
\text { the management and performance of the company. } \\
\text { Implementation of good governance principles is } \\
\text { consesponding author: first } \\
\text { Vebina }\end{array}$ \\
$\begin{array}{l}\text { Seeing the many achievements achieved by PT. } \\
\text { vebinadesi@gmail.com } \\
\text { Unilever Indonesia is primarily an award for GCG so } \\
\text { researchers are interested in examining how it is } \\
\text { applied and the constraints experienced. From the } \\
\text { results of this study it can be seen that the application } \\
\text { of GCG principles in the internal environment of PT. } \\
\text { Unilever Indonesia has been going well, although } \\
\text { sometimes it collides with changes that occur in the } \\
\text { internal environment so that there are adjustments that } \\
\text { must be made by all employees. The research method } \\
\text { used is descriptive qualitative. Qualitative descriptive } \\
\text { writing is writing that seeks to explain the current } \\
\text { problem solving based on data, present data, analyze } \\
\text { and interorete. } \\
\text { Keywords: Good Corporate Governance, GCG } \\
\text { Principles, Good Corporate Governance }\end{array}$ \\
\hline
\end{tabular}

\section{INTRODUCTION}

In the increasingly competitive business world competition, Good Corporate Governance or Corporate Governance becomes an important thing to consider. The number of business owners who want to get the maximum benefit, even by justifying any means. In the business world, it really needs to be instilled that getting profits is not the only goal in business. To develop the Indonesian economy, many people are needed to understand and apply business governance in their businesses. Corporate Governance is a set of mechanisms that are used to provide limits and direction and the performance of an organization or company Sampurno (2010). 
With the above phenomenon, it is necessary to apply GCG which can restore investor confidence. Implementation of good GCG principles is considered to have a positive impact on companies is one of the criteria that must be used by investors to analyze companies and invest their capital, Tjager et al (2003). The main purpose of GCG is to achieve corporate management transparency for users of financial statements. If the company can implement this GCG, the company's management performance will run smoothly and increase company profits are expected to continue to increase.

PT. Unilever Indonesia reviews GCG practices implemented and seeks to meet relevant requirements from international and national GCG best practices from time to time. The management carried out internal and external assessments to monitor the implementation of GCG from the five GCG principles of PT. Unilever Indonesia. In implementing Good Corporate Governance, it is able to prevent fraudulent actions such as insider trading, internal acquisitions and special transaction transactions that are detrimental to minority shareholders. In addition, the application of corporate governance can encourage the creation of an atmosphere of fair competition. If all companies can implement Good Corporate Governance, it is expected that the performance of companies in Indonesia can increase. From these actions can affect investors' views of investment in Indonesia.

The implementation of the Good Corporate Governance system is expected to be able to increase added value for all stakeholders that have the following objectives:

a. Improving efficiency, effectiveness, with a sustainable system of an organization that can contribute to the creation of the welfare of the company's stakeholders and is a solution in facing the challenges of the organization in the future.

b. Increase the legitimacy of the organization being managed by referring to the principles of governance in the company.

c. Fulfill and safeguard the rights and obligations of stakeholders.

The need for GCG implementation is important and must lead to measurable implementation. PT. Unilever Indonesia formulates and applies GCG principles and corporate work culture into business ethics guidelines.

\section{LITERATURE REVIEW}

According to Effendi (2009) in his book The Power of Good Corporate Governance, GCG is a company's internal control system that has the primary goal of managing significant risks to meet its business objectives through securing company assets and increasing the value of shareholders' investments in the long term. Good governance according to Agoes (2006) The system governing the relationship of the role of the Board of Commissioners, the role of the Board of Directors, shareholders and other stakeholders.

Corporate governance in essence concentrates on good ways to guarantee strategic decisions, can be done correctly and effectively. In addition, it can prevent conflicts of interest (conflict of interst) from various parties within the company (owners and top managers of the company). In a company, the interests between top management and shareholders must always be in line with the interests of a company.

\section{Benefits of Good Corporate Governance}

The application of good corporate governance to the company not only protects the rights of investors but also has many benefits and advantages for the company and 
members who have a direct or indirect relationship with the company. Many of the benefits gained by implementing good corporate governance in the company are as follows:

1. By implementing good corporate governance in companies can minimize agency costs, the costs arising from the delegation of authority to management, including other costs such as the use of resources in the company by management for personal affairs or supervision of management behavior.

2. Companies can minimize the cost of capital, which is the cost of capital that is charged if the company submits a loan to the bank or creditor. This is the result of managing a wellmanaged and healthy company that creates a positive reference for creditors.

3. Can increase the level of efficiency and can create more effective performance. These three things will create a positive influence on company performance, and company performance will increase. (Sakai \& Asaoka 2003; Balck et al., 2003).

4. By implementing Good corporate governance is proven to be able to avoid or minimize the misuse of authority by company officials in managing the company.

5. In the eyes of investors the value of the company will increase confidence in the management of the company. As investor confidence in the company increases, it will facilitate the company in requesting additional funds for various company needs, especially for expansion purposes. The results of research conducted by McKinsey \& Company (2002) prove that more than $70 \%$ of institutional investors are willing to pay more (reaching 26-30\% more expensive) shares of companies that implement good corporate governance compared to companies whose implementation is still doubtful.

The purpose of implementing GCG in particular is to create added value for interested parties. The principles in GCG in general Zarkasyi (2008) are as follows:

1. Transparency: in the openness of the process the means taken in deciding and openness in disclosing and providing valid information about the Company in the industry, which is easily accessible by all people in the company, food products, beverages and others as well as standards, principles, and the practice of organizing a healthy insurance business entity.

2. Accountability: Accountability is the clarity of functions, structures, systems and corporate accountability.

3. Responsibility: The form of responsibility is the company's compliance with applicable regulations.

4. Independence: a condition in which companies in an industry that are managed independently, professionally and free from personal interests that affect or suppress any party that is not in accordance with the laws and regulations in the field of insurance and business ethics values that include principles, standards, and implementation of a good insurance business.

5. Equality: balanced and fair equality in the fulfillment of the rights of the Stakeholders arising based on business agreements and regulations of the law in the field of insurance and the value of business ethics which includes principles, standards and implementation of good insurance business operations.

Factors of Application of Good Corporate Governance Principles

The application of GCG has two factors namely external factors and internal factors, which are mentioned as follows:

a. External factors 
1. Have a good legal system

2. Have examples of proper GCG implementation (best practices)

3. Building a value system that supports the implementation of GCG in the community

4. Have anti-corruption attitude in the company that operates

b. Internal factors

1. Having a corporate culture that supports the implementation of GCG

2. The company's risk control management is based on GCG standard rules

3. Having an effective audit system at the company

4. There is an attitude of information disclosure for the public

\section{Good Corporate Governance Mechanism}

Management of the company or also referred to as corporate governance, has a fairly broad definition. In a narrow sense, corporate governance is closely linked with managers, directors, auditors and shareholders. while broadly, corporate governance can increase company value, can make company performance more efficient, create greater profits, and obey applicable laws. The existence of these elements has functions and responsibilities related to the implementation of good corporate governance.

additional elements to complete the application of GCG (Agoes, 2011: 109), namely:

1. Institutional Ownership

According to Widarjo (2010: 25) Institutional Ownership namely: "Institutional Ownership is a condition when an institution has a stake in a company. These institutions are in the form of government institutions, private and foreign institutions. "

Whereas Thesarani (2016) explains that: "Institutional Ownership is a measure of institutional ownership owned by the end of the year measured in percentage of shares owned by institutional investors in the company."

From the expert opinion above namely Widarjo (2010: 25), and Theserani (2016), it can be concluded that institutional ownership is a measure of shares owned institutionally in a company at the end of the year.

The National Governance Policy Committee (KNKG) (2006) explains the board of commissioners namely:

"The Board of Commissioners is part of the corporate structure that has duties and responsibilities on an ongoing basis providing constructive criticism or suggestions to the board of directors who have implemented governance optimally. However, the board of commissioners may not participate in operational decision making "

Sembiring (2005) explains that the size of the board of commissioners is as follows:

"The size of the board of commissioners is the total of all members of the board of commissioners in a company" 
From this explanation from the Limited Company Law No.40 of 2007 paragraph 2, KNKG in 2006 and according to Sembiring in 2005, the conclusion was that the size of the board of commissioners is the total of all members of the board of commissioners who supervise the directors in carrying out the company's business activities.

\section{Independent Board of Commissioners}

Agoes and Ardana (2014: 110) are of the opinion that an Independent commissioner namely: "An independent commissioner and director is someone who is chosen as a representative of minority shareholders and that the party does not have the capacity to represent any party and is appointed solely based on background knowledge , experience and professional expertise it has that aims to carry out tasks in the interests of the company

\section{RESEARCH METHODS}

This type of research uses descriptive qualitative research, according to Muchtar (2013) suggests that a qualitative descriptive study describes all the symptoms or conditions that exist, namely the state of symptoms as they are.

This research is a qualitative research. The definition of qualitative research is research with observational methods that are described descriptively using the analytical skills of researchers supported by theoretical studies from various sources. Retrieval of data sources using purposive sampling techniques, namely how to take data samples with special characteristics in accordance with the purpose of the study. In this case the research aims to determine the application of Good Corporate Governance effect on PT. Unilever Indonesia

\section{Population and Research Samples}

a. Population

According to Sabar (2007) Population is the overall object of research. The population in this study were all employees of PT. Unilever Indonesia, amounting to 6000 people.

b. Samples and Sampling Methods

According to Sugiyono (2013: 118) the sample is part of the number and characteristics possessed by the population. The sampling method uses a non probability sampling technique, which is a sampling technique that does not provide the same opportunity or opportunity for each element or member of the population to be selected as a sample.

So this researcher used a sample of 10 respondents, because the number of employees at PT. Unilever Indonesia numbered 6000 people.

\section{Time and Place of Research}

a. Research time

This study begins by identifying the problem at the place that will be used as a research location, problem formulation. This research process requires time starting from May 2020. 


\section{b. Place of Research}

In conducting research in order to obtain the required data the writer took the location of the study at PT. Unilever Indonesia.

\section{Research Instruments}

According Sukmadinata (2011) states that a test that has characteristics that measure informants with a number of research questions and statements, which can be done by making an outline of the research objectives carried out.

\section{Data collection technique}

namely by making observations and surveys directly on the object of research in the form of a questionnaire to employees of PT. Unilever Indonesia.

\section{Method of collecting data}

The data collection method used in this study is to use the library research data collection method (libraray research) and field research. Literature research is conducted to obtain data on theories that can support research. Meanwhile, field research is carried out to know more clearly the situation and conditions in the field and compare them with the theory obtained.

\section{RESULTS AND DISCUSSION}

Good Corporate Governance or good corporate governance is very important to increase the company's trust in investors and shareholders. In fact, many companies make Good Corporate Governance one of the company's strategies to achieve goals optimally, even used as a measuring tool to assess the quality of the work structure of the company PT. Unilever Indonesia is open to tax authorities by covering up and not manipulating corporate income reports.

The use of email to convey information is very effective. PT. Unilever Indonesia reviews GCG practices implemented and seeks to meet relevant requirements from international and national GCG best practices from time to time. The management carried out internal and external assessments to monitor the implementation of GCG from the five GCG principles of PT. Unilever Indonesia.

In implementing GCG, it is able to prevent fraudulent actions such as insider trading, internal acquisitions and special relationship transactions that harm minority shareholders. In addition, the application of corporate governance can encourage the creation of an atmosphere of fair competition. If all companies can implement Good Corporate Governance, it is expected that the performance of companies in Indonesia can increase. From these actions can affect investors' views of investment in Indonesia.

The implementation of the Good Corporate Governance system is expected to increase added value for all stakeholders who have the following objectives:

a. Improving efficiency, effectiveness, with a sustainable system of an organization that can contribute to the creation of the welfare of the company's stakeholders and is a solution in facing the challenges of the organization in the future. 
b. Increase the legitimacy of the organization being managed by referring to the principles of governance in the company.

c. Fulfill and safeguard the rights and obligations of stakeholders.

These institutions are supported by a series of guidelines and means of control, including internal control systems, internal audit risk management systems, codes of business principles, Unilever business partner guidelines, sustainable agriculture guidelines, quality management systems, and business processes and standard operating procedures. PT. Unilever Indonesia received the Capital Market Award as the Best Listed Company twice in a row from the Financial Services Authority (OJK), the Indonesia Stock Exchange (IDX), KPI, and KSEL. The award shows external recognition for the company's strong commitment to the implementation of Good Corporate Governance.

Corporate Governance requires an organizational structure or set to achieve goals and monitor performance, Prihanto (2018). PT. Unilever Indonesia formulates and applies GCG principles and corporate work culture into business ethics guidelines.

\section{Transparency}

In the openness of the process the means taken in deciding and openness in disclosing and providing valid information about the Company in the industry, which is easily accessible by all people in the company in accordance with the provisions of the legislation in the field of food products, beverages and others as well as standards , principles, and practices of implementing a healthy insurance business entity

2. Accountability

In the accountability aspect discussed, it is about the clarity of functions, structures and audits so as to increase the company's performance to be effective and efficient which affects the company's production and income. The first thing that will be discussed is about the clarity of functions and structures within the company. Clarity of functions and structures within a company is very important, because it regulates human resources, the tasks that must be done and clarity in the person in charge of a company. The first part is about the company's structure. PT. Unilever Indonesia has a corporate structure with the highest position is the commissioner, and under the commissioner there is a president director who oversees the work of the directors and holders of positions below.

The second part is about the function of the management structure in a company, the board of commissioners, the board of directors, and other position holders in the company have their respective functions in the company. Each holds an important role and task for the progress and survival of the company. At PT. Unilever Indonesia has been functioning well, each position holder has an awareness and responsibility for the progress of the company he leads.

\section{Responsibilities}

The most important part in running a company is the company's responsibility. The forms of responsibility are those related to the surrounding environment and responsibilities to employees, government and customers. 


\section{CONCLUSIONS AND RECOMMENDATIONS}

\section{Conclusion}

The company is transparent because it is willing to provide the taxpayer Identification Number (NPWP) to researchers so that it can be evidence that the company obeys as a taxpayer. PT. Unilever Indonesia is open to tax authorities by covering up and not manipulating corporate income reports.

Means of conveying important information in the company environment are only conveyed to the holders of the highest positions, so that they will be announced to all employees below them. The use of email to convey information is very effective.

PT. Unilever Indonesia reviews GCG practices implemented and seeks to meet relevant requirements from international and national GCG best practices from time to time. The management carried out internal and external assessments to monitor the implementation of GCG from the five GCG principles of PT. Unilever Indonesia.

These institutions are supported by a series of guidelines and means of control, including internal control systems, internal audit risk management systems, codes of business principles, Unilever business partner guidelines, sustainable agriculture guidelines, quality management systems, and business processes and standard operating procedures. PT. Unilever Indonesia received the Capital Market Award as the Best Listed Company twice in a row from the Financial Services Authority (OJK), the Indonesia Stock Exchange (IDX), KPI, and KSEL. The award shows external recognition for the company's strong commitment to the implementation of Good Corporate Governance.

The need for GCG implementation is important and must lead to measurable implementation. Therefore PT. Unilever Indonesia formulates and applies GCG principles and corporate work culture into business ethics guidelines.

1. Transparency

In the openness of the process the means taken in deciding and openness in disclosing and providing valid information about the Company in the industry, which is easily accessible by all people in the company in accordance with the provisions of the legislation in the field of food products, beverages and others as well as standards , principles, and practices of implementing a healthy insurance business entity

2. Accountability

In the accountability aspect discussed, it is about the clarity of functions, structures and audits so as to increase the company's performance to be effective and efficient which affects the company's production and income. PT. Unilever Indonesia has a corporate structure with the highest position is the commissioner, and under the commissioner there is a president director who oversees the work of the directors and holders of positions below.

3. Responsibilities

The most important part in running a company is the company's responsibility. The forms of responsibility are those related to the surrounding environment and responsibilities to employees, government and customers. PT. Unilever Indonesia is a large company, of course, has an obligation to implement CSR to be able to survive in business competition. The form of CSR carried out by PT. Unilever Indonesia is 
providing health services, training for employees, providing places of worship, providing scholarships for outstanding employees.

4. Independence

There are three stages of decision making carried out by the company, the first stage is decision making by their respective division managers in making decisions by managers directly made in the field.

The second stage is decision making by the board of directors, at this stage usually the board of directors discusses the decisions taken by managers and also the right decision making that cannot be done by managers. And the third stage is decision making by active shareholders and board of directors through meetings.

5. Equality

Equality is an important principle because at this time the system of share ownership in companies is no longer individual, but joint ownership of company members. This becomes important because every element in the company must know every company's development.

\section{REFERENCE}

Agoes. (2011). Auditing Petunjuk Praktis Pemeriksaan Akuntan oleh Akuntan Publik. Jilid 1. Salemba Empat, Jakarta

Ali, H. (2020). Modul Business Ethics \& Good Governance Concept and Theories of Business Ethics.Universitas Mercu Buana.

Effendi, M.A. (2009). The Power of Good Corporate Governance Teori dan Implementasi. Jakarta : Salemba Empat.

Ibnu Purna., Hamidi., Prima. (2009). Perekonomian Indonesia Tahun 2008 Tengah Krisis Keuangan Global. Retrieved November 12, 2013. From (http://www.setneg.go.id/index.php?option=com_content\&task=view\&id=3698)

Juanda, A. Analisis Konseptual Good Corporate Governance.(2009).22November2013. https://researchreport.umm.ac.id/index.php/researchreport/article/view/185

https://acounting.binus.acid/good-corporate-governance-gcg. (10 Mei 2020, Jam 12.00)

Agoes. (2009). Good Corporate Governance. Jakarta : Gramedia. https://portalilmu.com/teori-corporate-governance. (12 Mei 2020, Jam 10.00)

Arifin, Z. (2005). Hubunganb antara Corporate Governance dan variabel Pengurang Masalah Agensi. Jurnal Ekonomi dan Bisnis.No.10 vol. 1. Fakultas Ekonomi Universitas Islam Indonesia.

Muchtar, S. (2013). http://eprints.uny.ac.id Metode penelitian deskriptif kualitatif. (29 April 2020, Jam 12.00).

Sampurno. (2010). Manajemen Stratejik: Menciptakan Keunggulan Bersaing yang Berkelanjutan. Yogyakarta: Universitas Gadjah Mada.

Tjager, I.N., Alijoyo. F.A., Djemat, H.R., Soembodo. B. (2003). Corporate Governance: tantangan dan kesempatan bagi komunitas bisnis Indonesia. Forum Corporate Governance in Indonesia (FCGI). Jakarta: Ikrar Mandiriabadi

Zarkasyi, M.W. (2008). Good Corporate Governance. Bandung: CV. Alfabeta 